\title{
Prediksi Kerusakan Tekan Bata Beton Berlubang Akibat Beban AKSIAL
}

\section{Compressive Damage Prediction of Hollow Concrete Masonry Under Axial Load}

\author{
Muhammad Ali Rofiq \\ Program Studi Teknik Sipil, Fakultas Teknik, Universitas Muhammadiyah Surakarta, \\ Jl. A. Yani Pabelan Kartasura Tromol Pos I Surakarta, 57102 Indonesia \\ e-mail:mar126@ums.ac.id
}

\begin{abstract}
ABSTRAK
Pembahasan mengenai pemodelan numerik dilakukan untuk mengevaluasi perilaku dinding bata beton berlubang akibat beban aksial. Pemodelan bata beton berlubang menggunakan elemen 3 dimensi dengan 8 nodal. Meshing 20 x $20 \mathrm{~mm}$ digunakan pada pemodelan. Pada pemodelan ini constraint yang digunakan untuk menghubungkan antar bata beton berlubang adalah tie constraints. Parameter elastik dan inelastik diperoleh dari persamaan tegangan regangan tekan beton. Evaluasi pemodelan numerik ditinjau dari perilaku kegagalan yang terjadi pada bata beton berlubang. Hasil dari pemodelan menunjukan bata beton bertulang mengalami retakan vertikal ditunjukan dengan adanya konsentrasi tegangan vertikal di tengah badan. Kegagalan tekan terjadi pada sambungan mortar antar bata beton berlubang.
\end{abstract}

Kata-kata kunci: Kerusakan Tekan, Dinding Bata Beton

\begin{abstract}
Discussion on numerical modeling is done to evaluate the behavior of hollow concrete masonry wall due to axial load. Hollow concrete block masonry model use 3-dimensional elements with 8 nodal. $20 \times 20 \mathrm{~mm}$ meshing is used in the modeling. The contraint that used to connect between hollow concrete block masonry is tie constraint. The elastic and inelastic parameters are obtained from the compressive stress strain stress equation. Evaluation of numerical modeling in terms of failure behavior that occurs in hollow concrete block masonry. The results of the modeling show reinforced concrete masonry experiencing vertical cracks is shown by the presence of a vertical stress concentration in the middle of the body. Compression failure occurs at the mortar connection between hollow concrete masonry.
\end{abstract}

Key words: Compressive Damage, Concrete Mansory Wall

\section{PENDAHULUAN}

Salah satu elemen konstruksi tertua yang masih sering digunakan sekarang adalah dinding bata (Furtmüller \& Adam, 2011). Sejak zaman kuno pasangan bata sudah banyak digunakan sebagai bahan bangunan termasuk sebagian besar warisan arsitektur dunia menggunakan konstruksi bata (Oliveira et al, 2006). Blok beton mempunyai daya dukung yang tinggi sehingga struktur pasangan bata dapat mengurangi biaya konstruksi (Xu et al, 2018). Konstruksi bata menggunakan kombinasi bata dan mortar yang kekuatan tekannya juga bergantung pada lekatan keduanya (Vyas \& Reddy, 2010). Drougkas et al. (2016) telah melakukan studi tekan terhadap tumpukan batu bata menggunakan pelekat mortar yang menujukkan bahwa kekuatan batu bata lebih tinggi dari pada mortar sehingga kegagalan didominasi oleh mortar. Analisa perilaku batu bata beton berlubang secara eksperimen dan numerik masih terus berkembang, seperti yang dikemukakan oleh Barbosa et al (2010). Pasangan batu bata beton berlubang terdiri dari geometri yang berbeda dan dilekatkan satu sama lain menggunakan mortar yang membentuk blok penuh saat eksperimen sehingga perilaku mortar tidak diketahui (Barbosa, 2010). Kekuatan tekan pasangan batu bata menjadi faktor utama penentu perilaku pasangan batu bata (Drougkas $\mathrm{t}$ al, 2016). Zhou et al. (2017) melakukan eksperimen terhadap bata berlubang 5 tingkat yang menunjukkan bahwa deformasi pasangan batu bata secara signifikan dipengaruhi oleh kekuatan mortar. Pada akhir 1980an pasangan bata mulai diprediksi perilakunya menggunakan metode elemen hingga dengan model linier dan non-linier yang terbukti mampu memprediksi pola keretakan dan kekuatan tekan (C. V. U. Vyas dan B. V. V. Reddy, 2010). Silva et al. (2017) melakukan pemodelan numerik 2 dimensi pada pasangan batu yang menunjukkan bahwa analisa elemen hingga dapat menggambarkan mekanisme kegagalan dan pola retak dari dinding pasangan batu. Tujuan dari penelitian adalah untuk mengetahui prediksi secara numerik kerusakan tekan pada bata beton berlubang jika dibebani secara aksial.

\section{METODE PENELITIAN}

Penelitian dlmulai dengan persiapan data properti dan geometri batu bata beton berlubang. Desain geometri dan properti dinding pasangan bata diambil dari referensi Zhou et al. (2017) Pendefinisian material konstitutif tekan dan tarik beton didekati dengan persamaan teganganregangan. Kurva tegangan-regangan kuat tekan beton didekati dengan persamaan yang dikembangkan oleh Razvi \& Saatcioglu (1999). Sementara kurva tegangan-regangan kuat tarik beton didekati dengan persamaan yang dikembangkan oleh Hsu dan Zang (1996). Data tegangan regangan diformulasikan ke dalam data tegangan lelehregangan elastis dan regangan elastis - damage parameter berdasarkan input parameter pada program ABAQUS (2012). Damage parameter diperoleh dari perhitungan Fracture Energy (Rofiq et al, 2019). Pada pemodelan ini dilakukan studi parameter persamaan tegangan-regangan terhadap ABAQUS menggunakan model kubus beton. Rofiq et al. (2019) telah melakukan studi parameter 
persamaan tegangan-regangan pada kuat tekan dan tarik beton menggunakan ABAQUS untuk membuktikan bahwa input parameter beton sudah sesuai dengan pendekatan persamaan yang digunakan pada pemodelan. Input parameter material beton pada ABAQUS disajikan pada Tabel 1.

Tabel 1. Properti Material

\begin{tabular}{|c|c|}
\hline Variabel & Nilai \\
\hline Berat Jenis (kg/m3) & 2400 \\
\hline Modulus Elastisitas $(\mathrm{MPa}$ ) & 25438.6 \\
\hline Poison's Ratio & 0.2 \\
\hline Sudut dilatasi & 40 \\
\hline Eksentrisitas & 0.1 \\
\hline FBO/FCO & 1.16 \\
\hline$K$ & 0.667 \\
\hline Parameter viskositas & 0,001 \\
\hline Tegangan leleh tekan $(\mathrm{MPa})$ & 31 \\
\hline Tegangan leleh tarik $(\mathrm{MPa})$ & 2.89 \\
\hline
\end{tabular}

Parameter-parameter pada Tabel 1 diinput pada perilaku elastik dan plastik beton. Berat jenis, poison's ratio, dan elastisitas dimasukkan ke dalam perilaku elastik beton. Sementara data tegangan-regangan dan damage parameter dimasukkan ke dalam perilaku plastik Concrete Damage Parameter. ABAQUS merekomendasikan nilai parameter eksentrisitas, $F B O / F C O$, dan $K$. Nilai sudut dilatasi dan viskositas disesuaikan berdasarkan hasil studi parameter kubus beton [12]. Spesimen pada peneltian ini dimodelkan struktur dinding 5 tingkat dengan dua pasangan bata beton berlubang berbeda dipasang tiap tingkat dengan pelekat mortar seperti ditunjukkan pada gambar 1. Mortar didesain menggunakan kuat tekan 6.75 MPa. Kedua ujung dinding dipasang blok baja untuk menekan dan menahan struktur dinding saat pembebanan Perletakan blok baja bawah dan atas menggunakan encastre yang tersedia pada ABAQUS. Meshing yang digunakan adaah hexahedral dengan ukuran $20 \mathrm{~mm}$ x $20 \mathrm{~mm}$. Pembebanan diletakkan pada blok baja atas dengan beban tekanan merata lateral displacement uniaxial sampai runtuh.

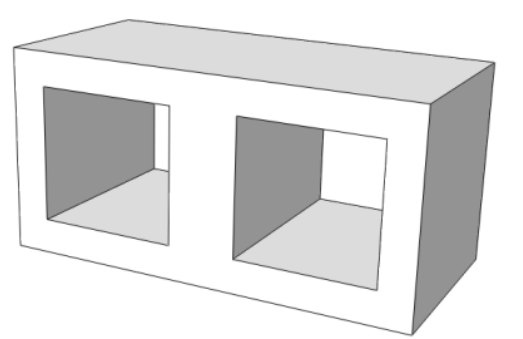

(a)

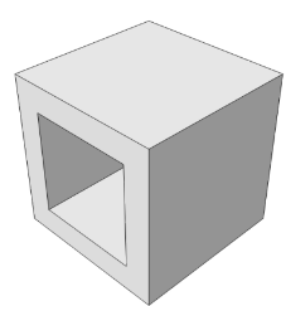

(b)
Gambar 1. Blok batu bata beton berlubang : (a) dua lubang dan (b) satu lubang

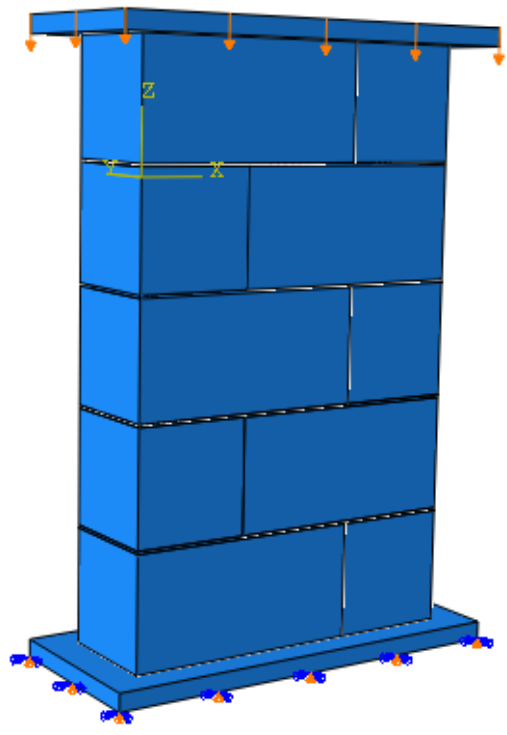

Gambar 2. Pemodelan pasangan batu bata beton berlubang

\section{HASIL DAN PEMBAHASAN}

Pada penelitian ini, spesimen batu bata beton berlubang dimodelkan menggunakan mortar pada setiap layer. Penelitian dilakukan untuk menjelaskan pola kerusakan tekan, kekuatan tekan, kurva tegangan-regangan, dan tegangan puncak spesimen. Pola kerusakan batu bata beton berlubang ditunjukkan pada Gambar 1. Pada spesimen keretakan dimulai pada mortar di pertemuan pasangan spesimen dilihat dari konsentrasi kerusakan tekan. Hal ini disebakan karena modulus elastisitas dan kuat tekan mortar yang lebih rendah dibandingkan batu bata beton berlubang. Pada bagian permukaan depan spesimen, keretakan terjadi sepanjang arah vertikal ke bagian bawah spesimen. Pada permukaan samping, keretakan terjadi pada tengah badan sepanjang tinggi spesimen. Hal ini menunjukan bahwa pola keretakan yang terjadi pada bata beton bertulang dominan pada arah vertikal blok dan mortar yang dibuktikan oleh eksperimen yang dilakukan oleh $\mathrm{Wu}$ et al. (2013). Perilaku kegagalan batu bata beton berlubang akibat beban aksial ditunjukkan oleh kurva tegangan-regangan pada gambar 2 . Berdasarkan kurva tegangan-regangan, fase elastik terjadi dari regangan plastis 0 sampai regangan plastis 0.00002 . Setelah fase elastik kurva mengalami perubahan signifikan yang menunjukkan bahwa dimulainya fase non linier. Beban puncak terjadi pada tegangan $36 \mathrm{MPa}$ dan regangan plastis 0.0008. Ketika kurva naik mencapai puncak, dilanjutkan kurva turun secara signifikan. Hal ini dapat terjadi karena setelah kurva mencapai puncak, beton sudah mengalami crack yang terjadi retak vertikal pada spesimen. Analisa non linier menggunakan ABAQUS dilakukan untuk mengidentifikasi kerusakan dominan. Mekanisme kerusakan lentur, tekan, dan tarik dianalisa dari hasil pemodelan. Dinding bata yang diberikan tekanan aksial memlilki pola kerusakan yang menunjukkan konsentrasi kerusakan menyebar secara secara diagonal pada bagian tengah. 


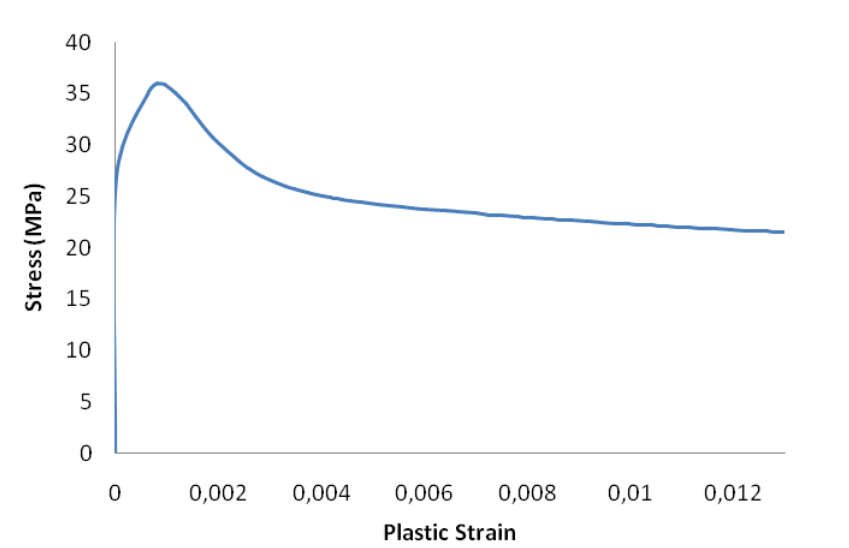

Gambar 3. Hubungan tegangan-regangan plastic

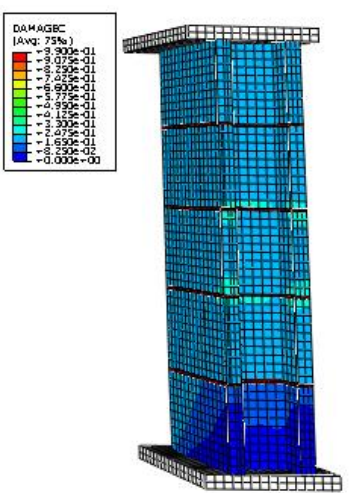

(a)

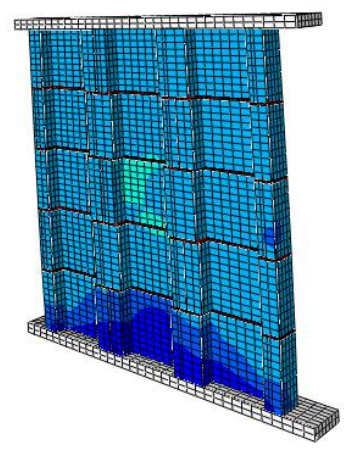

(b)
Gambar 4. Kerusakan akibat tekan: (a) potongan melintang dan (b) potongan memanjang

\section{KESIMPULAN}

Paper ini menyajikan hasil investigasi analisis pemodean dinding pasangan bata berlubang. Tujuan dari penelitian ini adaah untuk mengetahui perilaku dinding pasangan bata beton. Perilaku bata beton berlubang dipengaruhi oleh kontribusi mortar pada setiap tingkat antar blok bata. Konsentrasi kegagalan model dimulai pada mortar. Hal ini dapat terjadi karena mortar memiliki kuat tekan yang lebih rendah dibandingkan dengan blok beton berlubang. Fase non linier terjadi ketika mortar sudah mengalami kegagalan. Hal ini mengindikasikan bahwa mortar mempunyai pengaruh yang cukup signifikan. Selain pada mortar, konsentrasi kerusakan juga terjadi pada bagian tengah model. Hal ini terjadi karena beban pada model satu arah. Penelitian ini diharapkan dapat menjadi referensi penelitian selenjutnya mengenai prediksi secara numerik kerusakan susunan bata berlubang akibat beban aksial.

\section{DAFTAR PUSTAKA}

A. Drougkas, P. Roca, and C. Molins, "Compressive strength and elasticity of pure lime mortar masonry," Mater. Struct. Constr., vol. 49, no. 3, pp. 983-999, 2016, doi: 10.1617/s11527-015-0553-2.

B. Q. Silva, A. Pappas, J. M. Guedes, F. da Porto, and C. Modena, "Numerical analysis of the in-plane behaviour of three-leaf stone masonry panels consolidated with grout injection," Bull. Earthq. Eng., vol. 15, no. 1, pp. 357-383, 2017, doi: 10.1007/s10518-016-9969-5.

C. S. Barbosa, P. B. Lourenço, and J. B. Hanai, "On the compressive strength prediction for concrete masonry prisms," Mater. Struct. Constr., vol. 43, no. 3, pp. 331-344, 2010, doi: 10.1617/s11527009-9492-0.

C. V. U. Vyas and B. V. V. Reddy, "Prediction of solid block masonry prism compressive strength using FE model," Mater. Struct. Constr., vol. 43, no. 5, pp. 719-735, 2010, doi: 10.1617/s11527-009-95249.

Dassault Systèmes Simulia, “Abaqus 6.1 2," Abaqus 6.12, 2012.

D. V. Oliveira, P. B. Lourenço, and P. Roca, "Cyclic behaviour of stone and brick masonry under uniaxial compressive loading," Mater. Struct. Constr., vol. 39, no. 286, pp. 247-257, 2006, doi: 10.1617/s11527-005-9050-3.

F. Wu, G. Li, H. N. Li, and J. Q. Jia, "Strength and stressstrain characteristics of traditional adobe block and masonry," Mater. Struct. Constr., vol. 46, no. 9, pp. 1449-1457, 2013, doi: 10.1617/s11527-012-9987y.

M. A. Rofiq, H. Alrasyid, D. Iranata, and D. Irawan, "Prediksi Perilaku Lentur Kolom Beton Bertulang Mutu Tinggi Terhadap Kombinasi Beban Perpindahan Monotonik dan Aksial Rendah," J. Apl. Tek. Sipil, 2019, doi: 10.12962/j2579891x.v17i1.4899.

Q. Zhou, F. Wang, F. Zhu, and X. Yang, "Stress-strain model for hollow concrete block masonry under uniaxial compression," Mater. Struct. Constr., 2017, doi: 10.1617/s11527-016-0975-5.

S. Razvi and M. Saatcioglu, "CONFINEMENT MODEL FOR HIGH-STRENGTH CONCRETE," J. Struct. Eng., pp. 281-289, 1999.

T. Furtmüller and C. Adam, "Numerical modeling of the in-plane behavior of historical brick masonry walls," Acta Mech., vol. 221, no. 1-2, pp. 65-77, 2011, doi: 10.1007/s00707-011-0493-z.

T. T. C. Hsu and L.-X. Zhang, "Tension Stiffening in Reinforced Concrete Membrane Elements," ACI Struct. J., vol. 93, no. 1, pp. 108-115, 1996.

W. Xu, X. Yang, and F. Wang, "Experimental investigation on the seismic behavior of newly-developed precast reinforced concrete block masonry shear walls," Appl. Sci., vol. 8, no. 7, pp. 1-16, 2018, doi: 10.3390/app8071071. 
